\title{
焼成発泡法による $\mathrm{CaTiO}_{3}$ 多孔質支持体の作製
}

\author{
伊藤秀章・浅野 洋・永田 誠・岩原弘育 \\ 名古屋大学理工科学総合研究センター，464-01 名古屋市千種区不老町
}

\author{
Preparation of $\mathrm{CaTiO}_{3}$ Porous Substrate by Foam-Burning Method \\ Hideaki ITOH, Hiroshi ASANO, Makoto NAGATA and Hiroyasu IWAHARA \\ Center for Integrated Research in Science and Engineering, Nagoya University, Furo-cho, Chikusa-ku, Nagoya-shi 464-01
}

\begin{abstract}
$\mathrm{CaTiO}_{3}$ porous substrates required for spin-coating of mixed conductor $\mathrm{Ca}(\mathrm{Ti}, \mathrm{Fe}) \mathrm{O}_{3}$ films were prepared by a foam-burning method. Mixtures of calcined $\mathrm{CaTiO}_{3}$ powder and foaming agents such as corn starch, wheat starch $\mathrm{D}(+)$-glucose and carbon black were heated gradually up to $500^{\circ} \mathrm{C}$, then kept at $500^{\circ} \mathrm{C}$ for $2 \mathrm{~h}$ and finally sintered at $1350^{\circ} \mathrm{C}$. Relatively large pores above $15 \mu \mathrm{m}$ in diameter were formed when $15-35$ mass $\%$ corn starch was used as a foaming agent. Pore diameter distribution broadened with wheat starch. Sintered compacts with pore diameters as small as $5-10 \mu \mathrm{m}$ were prepared by using $15-25$ mass $\%$ carbon black or $D(+)$ glucose. The addition increased the mechanical properties of the spin-coated substrate. Gas permeability was found to increase according to the order; corn starch $>$ wheat $\operatorname{starch}>D(+)$-glucose $\geqq$ carbon black for a fixed amount of addition. An accelerated increase in the gaseous permeability was ascertained with increasing amount of foaming agent. $\mathrm{A} \mathrm{CaTiO}_{3}$ porous substrate prepared with 20 mass $\%$ carbon black or 40 mass $\%$ wheat starch exhibited sufficiently high mechanical strength for the thermal cyclic process of spin-coating and subsequent sintering.

[Received May 19, 1997; Accepted August 7, 1997]
\end{abstract}

Key-words : Porous substrate, Calcium titanate, Foam-burning method, Foaming agent, Spin-coating

\section{1. 緒 言}

高純度のチタン酸カルシウム $\left(\mathrm{CaTiO}_{3}\right)$ は，典型的なペロ ブスカイト型構造をもつ誘電体結晶であるが1)，4 価のチタン の一部を低原子価のイオンで置換固溶させた酸化物は，700 $1000^{\circ} \mathrm{C}$ 高温域で電子又はホールと酸化物イオンの混合導電 体であることが知られている2),3)。この混合導電体を隔壁とし て 2 室を設け，一方を高酸素分纴，他方を低酸素分圧として， 両ガ久室に酸素分圧差をつけると, 高温で電極や外部回路を必 要々しない酸素の電気化学的抽出器を作動させることが可能で ある4）著者らは， $\mathrm{CaTiO}_{3}$ に鉄をドープした電解質 $\mathrm{Ca}(\mathrm{Ti}$, $\mathrm{Fe}) \mathrm{O}_{3}$ が, 化学的安定性や機械的強度に優れた混合導電体で 㐫ることに注目し, 電解質のオ一ム損が少ない高効率の酸素抽 出器を開発するために, CVD 法5)やスピンコーティング法6)に よる $\mathrm{Ca}(\mathrm{Ti}, \mathrm{Fe}) \mathrm{O}_{3}$ の薄膜化を試みてきた。しかし, 電解質薄 膜の膜厚が500 $\mu \mathrm{m}$ 以下になると, 薄膜の機械的強度が低下す るので, 通気性のある多孔質支持体上に緻密な電解質薄膜を コーティングすることが必須の課題となっている.

上記の目的に適した多孔質支持体としては, まず材料が化学 的に安定で山ること, 貫通気孔率が多く, 高いガ久透過率を有 すること, しかも機械的強度に優れる材料であることが必要で ある、また, 電解質との接合強度に優れ, 熱サイクル作動に対 しても安定な熱・機械的性質を有する材料が望ましい。しか し, 混合導電体を用いる酸素の選択的透過膜デバイスを設計す る観点から，このような多孔質支持体を調製した報告例はほ上 んどなく，寺岡らによる $(\mathrm{La}, \mathrm{Sr}) \mathrm{CoO}_{3}$ 系多孔体の作製例7)が 報告されているにすぎない。

本研究では, $\mathrm{Ca}(\mathrm{Ti}, \mathrm{Fe}) \mathrm{O}_{3}$ と熱膨張率が近く, 化学的安定 性及び接合強度の点でも良好な支持体となりうる材料として $\mathrm{CaTiO}_{3}$ を選び，上述の要件を満足する多孔質支持体を作製す ることを目的とした。調製法としては各種有機系発泡剂を用い る焼成発泡法を採用し，多孔質体の組織及びガ久透過性に及ぼ す焼結条件と発泡剂を含む原料組成の影響を詳細に調べた。

\section{2. 実験方法}

\section{1 多孔質支持体の作製}

図 1 に, $\mathrm{CaTiO}_{3}$ 多孔質支持体の作製方法を示す。出発原料 には市販の $\mathrm{CaCO}_{3}$ 及び $\mathrm{TiO}_{2}$ 試薬を用い，これらを所定量秤 量し，ポットミルを用いてエタノール中で10h 混合した。その 後, 混合物中のエタノールを揮発除去し, 金型を用いて円柱状 に成形して，これを空気中， $1100 \sim 1200^{\circ} \mathrm{C}$ 温度で $10 \mathrm{~h}$ 仮焼 した，仮焼後の試料をアルミナ乳鉢で細かく粉砕し，更にベン

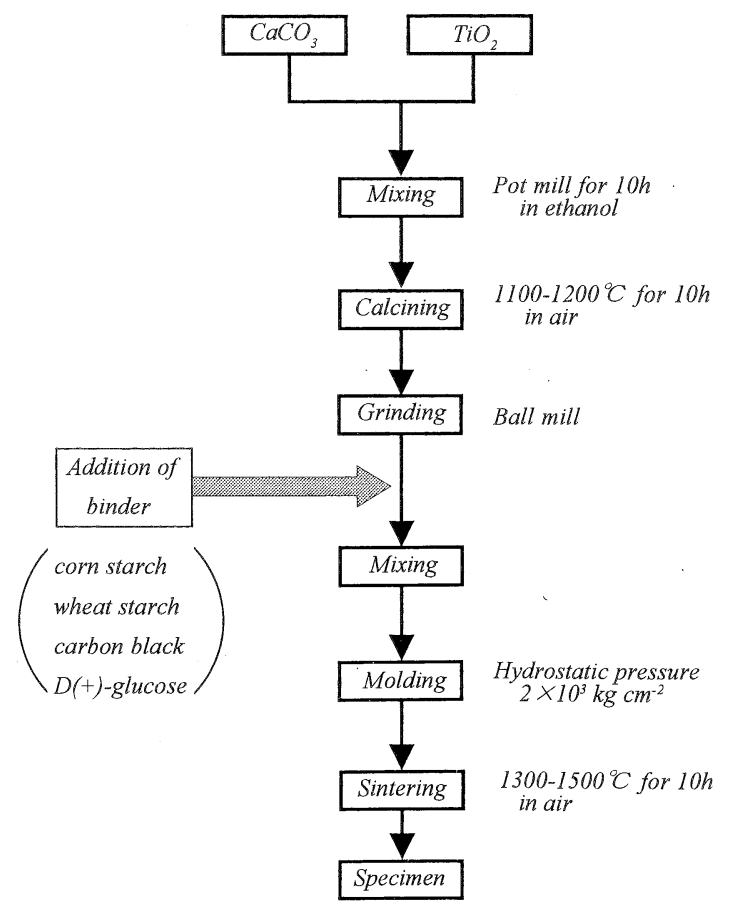

Fig. 1. Procedure for preparation of $\mathrm{CaTiO}_{3}$ porous substrate. 
ゼンを溶媒に用いて遊星型ボールミルにより粉䂥した。この微 粉末の一部圶採取し X 線回折で試料の結晶相が $\mathrm{CaTiO}_{3}$ 単相 であることを確認した。次に，この $\mathrm{CaTiO}_{3}$ 溦粉末に発泡剂を 所定比で乾式混合した。本実験で使用した発泡剂は，市販のと うもろこしデンプン (corn starch, $\left.\left(\mathrm{C}_{6} \mathrm{H}_{10} \mathrm{O}_{5}\right)_{n}\right)$ ，小麦デンフ ソ (wheat starch, $\left.\left(\mathrm{C}_{6} \mathrm{H}_{10} \mathrm{O}_{5}\right)_{n}\right)$, カーボンブラック (carbon black), ブドウ糖 $\left(\mathrm{D}(+)\right.$-glucose, $\left.\mathrm{C}_{6} \mathrm{H}_{12} \mathrm{O}_{6}\right)$ の 4 種類である. $\mathrm{CaTiO}_{3}$ 上発泡剂の混合粉末を, 再び金型で円柱状に成形し, $2 \times 10^{3} \mathrm{~kg} / \mathrm{cm}^{2}$ の静水压でプレスし, 空気中, $1300 \sim 1500^{\circ} \mathrm{C}$ の温度で $10 \mathrm{~h}$ 焼結し，多孔質焼結体を得た。なお，加熱処理に 伴う発泡剤の蓺的変化は，あらかじわ熱重量分析 (TG) で調 べ, それぞれの熱重量変化の結果を考虑して, 最終焼結の際の 昇温プログラムを設定した。

\section{2 多孔質支持体の観察評洒及びガス透過試験}

円柱状の試料の外寸及び質量を正確に計り，多孔質体のかさ 密度㞗めた，求めた密度と理論密度子り相対密度及び気孔率 を算出した。また，多孔質支持体の破断面の微楧造を走査型電 子顕微鏡（SEM；日立製作所製，S-2400形）により観察した. SEM 写真の細孔径を直接測定し，統計的処理により多孔質体 の平均細孔径を求めた。

ガ久透過試験には，直径 $10 \mathrm{~mm}$ ，厚さ $0.85 \mathrm{~mm}$ に加工した 多孔体試料を上下からガラ又管で挟み付けた測定用セルを用い た. 試料側面及びガラ久管の隙間からのガ久漏れを防止するた めに，周囲をエポキシ樹脂によりシールし，一方から窒素ガ久

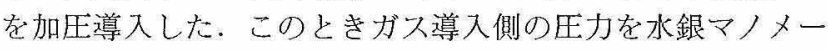
ターで測定し，試料を透過してくるガスの流量を泡流量計を用 いて測定した。以上のガス娐過試験はいずれも空温において 行った.

\section{1 気孔率に及ば \\ 3. 結果及び考察}

図 2 に, 発泡剤の熱重量分析結果を示す。搨温速度は $5^{\circ} \mathrm{C} /$ min である. 小考デンプン，とうもろこしデンプン及びカーボ ソブラックでは，いずれも同様の熱重量変化を示し，200〜

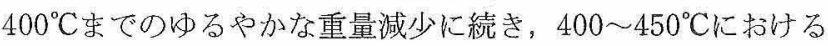
燃焼による大きな重量減少が認められる。一方, ブドウ糖は $100^{\circ} \mathrm{C}$ 付近から比較的急速に熱分解が生じ， $250^{\circ} \mathrm{C}$ 以上ではほ とんど一定の重量となっていることが分かる. 以上の熱重量分 析の結果と発泡剂の燃焼，焼去過程に関する予備実験を考虑し て，多孔体の焼結のさいの最適昇温プログラムを次のように決 定した。すなわち，発泡偊が然焼，焼去する約 $500^{\circ} \mathrm{Cむでは}$ $1.6^{\circ} \mathrm{C} / \mathrm{min}$ でゆっくりと昇温し，その後発泡剂を完全に焼去さ

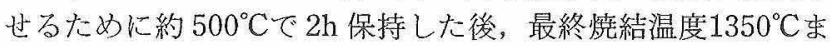
で $3^{\circ} \mathrm{C} / \mathrm{min}$ の速度で界温した。

図 3 K，各種発泡剂を20 mass\%添加して上記の方法で作製 した多孔体の破断面のSEM 写真を示す。発泡剤の種類によ り，気孔の大きさ及び分布に大きな相違が観察される。発泡剤 としてデンプン類を用いると，比較的大きな $15 \mu \mathrm{m}$ 以上の気 孔が生成する，とうもろこしデンプンでは細孔径分布が狭いの に対して，小麦デンプンでは $5 \mu \mathrm{m}$ 程度の細孔も見られ細孔径 分布はかなり広い。一方，カーボンブラックやブドウ糖を用い た場合には細孔径が 5 10 $\mu \mathrm{m}$ と小さくなることが分かる。亦 たブドウ糖に比ベて，カーボンブラックでは細孔径の分布が より均一であることが認められる. 細孔径及びその分布には， 成形体中の $\mathrm{CaTiO}_{3}$ と発泡剂之の混合状態及び暁去過程が大き く影響していると考えられる。すなわち，図 2 からも明らか なように分子量の大さなデンプン類の分解・焼去は比較的稳や

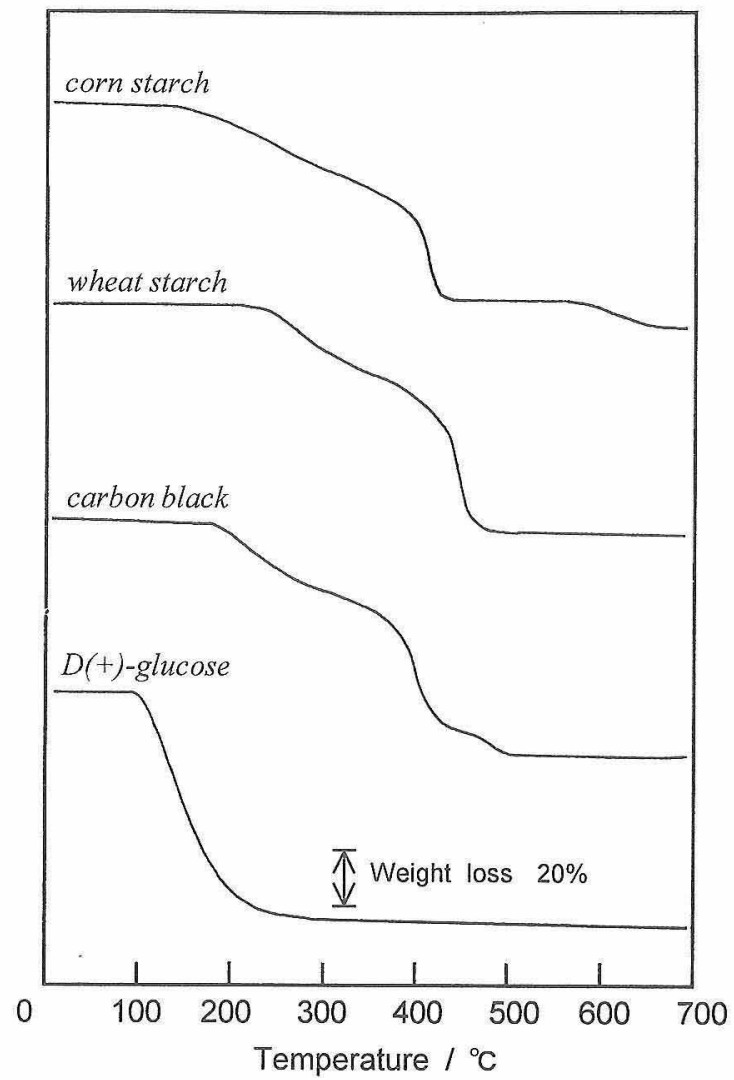

Fig. 2. Thermogravimetric analyses of foaming agents. Heating rate: $5^{\circ} \mathrm{C} / \mathrm{min}$.

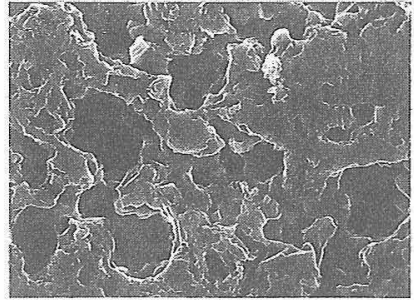

a

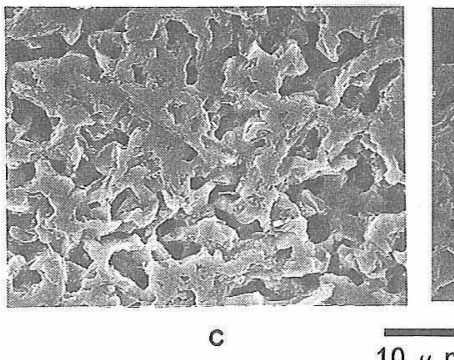

$10 \mu \mathrm{m}$
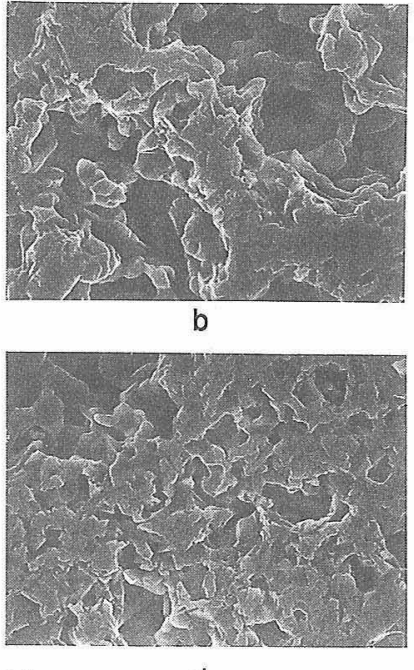

Fig. 3. SEM photographs of fractured porous substrate after sintering. Added amount of foaming agent: 20 mass\%. Foaming agent: (a) corn starch, (b) wheat starch, (c) carbon black, (d) $\mathrm{D}(+)$-glucose.

かに進むので, 粒子径の大きな発泡組織が焼結後むで取り残さ れ，細孔径が大きくなる. 小麦デンプンのほうがとうもるこし デンプンより細孔径分布が広いのは, 発泡剂の粒径と粒径分布 が若干大きいためであろう。一方，ブドウ糖の粒子径は 10 $\mu \mathrm{m}$ 以上と大きいために分散性は悪いが，その分解は比較的低 温から開始し（図 2 参照），成形体の収縮とともに細孔径も小 
さくなったもの上推察される.カーボンブラックの場合には， はじめから粒子径が数 $\mu \mathrm{m}$ と小さく，また混合時の粒子分散も 良好であり，敩細な細孔と均一な細孔径分布が得られたものと 考学られる。

図 4 は，発泡剂をカーボンブラックとして，その添加量を変 化させたときの多孔体破面の SEM 写真である。. 発泡剂無添加 の場合は，相対密度95\%以上の緻密な焼結体が得られている。 カーボンブラックの添加量が10 mass\%以下では細孔径は小さ く，また気孔の数も少ないので，ほとんどが閉気孔であると考 えられる。添加量の増加とともに閉気孔から開気孔の量が増加 し，スアルトン構造がかなり広い範囲で観察される。このよう な添加量に伴う多孔体微構造の变化はカーボンブラック以外の 発泡剤を用いた場合にも同様に観察された。

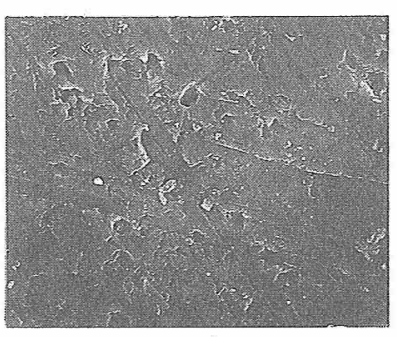

a
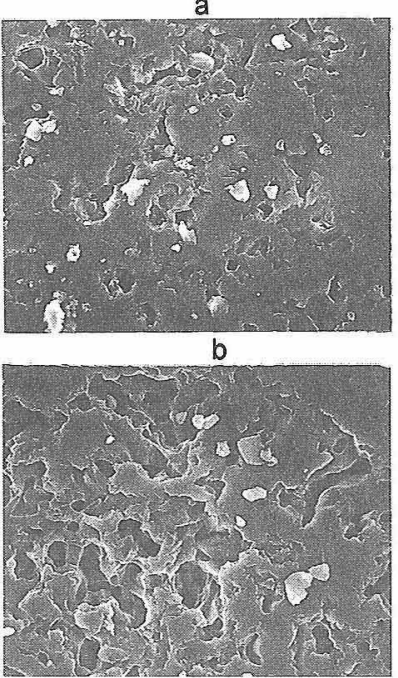

c

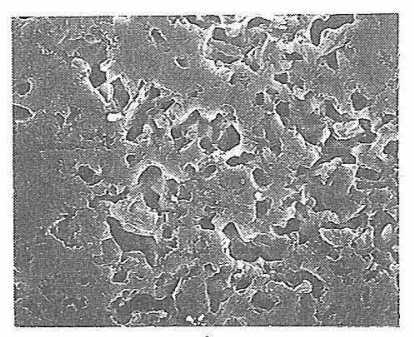

d
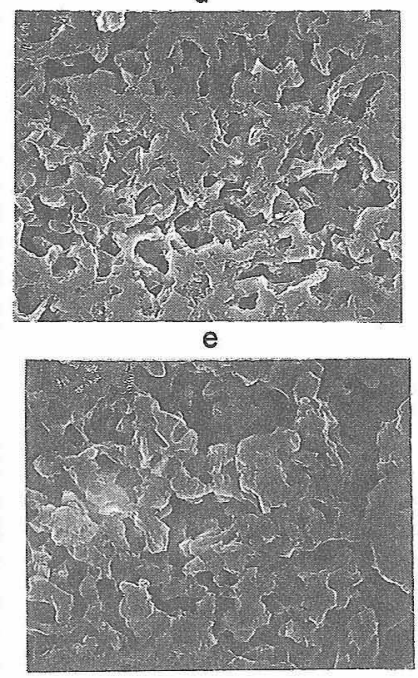

f $\overline{10 \mu \mathrm{m}}$

Fig. 4. SEM photographs of fractured porous substrate after sintering. Foaming agent: carbon black. Added amount: (a) 0 mass $\%$, (b) 5 mass $\%$, (c) 10 mass $\%$, (d) 15 mass $\%$, (e) 20 mass\%, (f) 25 mass $\%$.

Table 1. Sinterablility and Gas Permeability of Porous Substrates

\begin{tabular}{ccccccccc}
\hline \multirow{2}{*}{$\begin{array}{c}\text { Added } \\
\text { amount } \\
\text { (mass\%) }\end{array}$} & \multicolumn{2}{l}{ Corn starch } & \multicolumn{2}{c}{ Wheat starch } & \multicolumn{2}{c}{ Carbon black } & \multicolumn{2}{c}{ D(+)-glucose } \\
\cline { 2 - 8 } & S & P & S & P & S & P & S & P \\
\hline 5 & 0 & $\times$ & 0 & $\times$ & 0 & $\times$ & 0 & $\times$ \\
10 & 0 & $\triangle$ & 0 & $\triangle$ & 0 & $\times$ & 0 & $\times$ \\
15 & 0 & 0 & 0 & 0 & 0 & 0 & 0 & $\times$ \\
20 & 0 & 0 & 0 & 0 & 0 & 0 & 0 & 0 \\
25 & 0 & 0 & 0 & 0 & 0 & 0 & $\times$ & $\times$ \\
30 & 0 & 0 & 0 & 0 & $\times$ & $\times$ & $\times$ & $\times$ \\
35 & 0 & 0 & 0 & 0 & $\times$ & $\times$ & $\times$ & $\times$ \\
40 & $\times$ & $\times$ & 0 & 0 & $\times$ & $\times$ & $\times$ & $\times$ \\
45 & $\times$ & $\times$ & $\times$ & $\times$ & $\times$ & $\times$ & $\times$ & $\times$ \\
\hline
\end{tabular}

S: Sinterability, P: Permeability; $\bigcirc$ : Good, $\triangle$ : Medium, $x$ : Poor
表 1 に, 発泡剂の種類 と添加量が多孔体の焼結性とガ久透過 性に及ぼす影響を定性的になとめてめる。ここで，○印は良好 な焼結性またはガス透過性を示したもの， \印はこれが中程度 のもの，×印をしたものは，焼結性が恶く焼結後に形状の整っ た均一な多孔体として回収することができなかったものであ る. 各発泡刘について共通に言えることは，添加量が増加する と焼結体をエメリーペーパーで厚さ $0.85 \mathrm{~mm}$ に加工ずる段階 で，亀裂が入ったり破壊したりして，多孔体の機械的強度が低 下する傾向が認められた，表から明らかなように，良好な焼結 性を示す発泡㓮の添加量範囲は発泡剤によって異なり，デンプ ン類は 0 40\% と比較的広いが，カーボンブラック及びブドウ 糖では, 約 $25 \%$ までであった. カーボンブラックを多量に添 加した場合には焼結体中に $\mathrm{CaTiO}_{3}$ の強固な久ケルトン錸造が 形成されにくく，機械的強度が低下したのであるう。また，ブ ドウ糖を発泡乵に用いたとき焼結性が悪いのは，混合及び成形 時の分散性が良好ではないためでめる。

焼成発泡法では，発泡剂の添加率の増加とともに貫通気孔率 も増加するであるうという結果が容易に推論される。図 5 に, 烓結体の気孔率に対する発泡剂の添加量の依存性を示す。いす れの発泡剤を添加した場合においても, 発泡剤の添加率の増加 とともに気孔率は増加するが, その増加率は添加量とともに娍 少していく傾向が確認される. むた，SEM 写真から見積もっ た平均細孔程と発泡剂の添加量を比較主ると, 添加量の増加之 ともに細孔径が次第に大きくなることが確認された。

上述の気孔率の増加傾向については, 細孔の生成機構加ら次 のように考察することができる。すなわち，発泡剂の添加率が 低い場合，然故により成形体中に一様に分散した細孔はそれぞ れ独立して生成する。しかし, 添加量が増加すると発泡剂が広 範囲につながって抢り，複数の細孔がお互いに接合することに よって，共有する細孔久ペースの割合が增してくることにな る.その結果, 細孔体積の增加が減少する, つ方, 発泡剂の 添加量の増加とともに全体の細孔体積の増加上, 同時に細孔同 士の接合による細孔体積の减少とが相殺する結果, このような 傾向が観察されたものと考えられる. 発泡剂が完全に焼去する

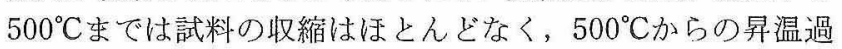
程で $\mathrm{CaTiO}_{3}$ の焼結過程に入る. 図 5 から, 焼結後は発泡剤の 添加量に対して，更に0〜20\%程度収縮することが分かる。

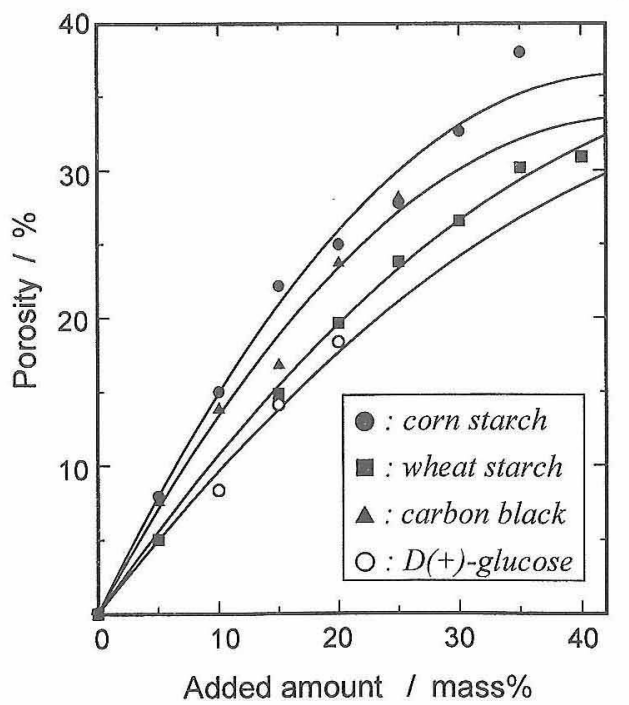

Fig. 5. Relationship between the porosity of sintered substrate and the added amount of foaming agent. 

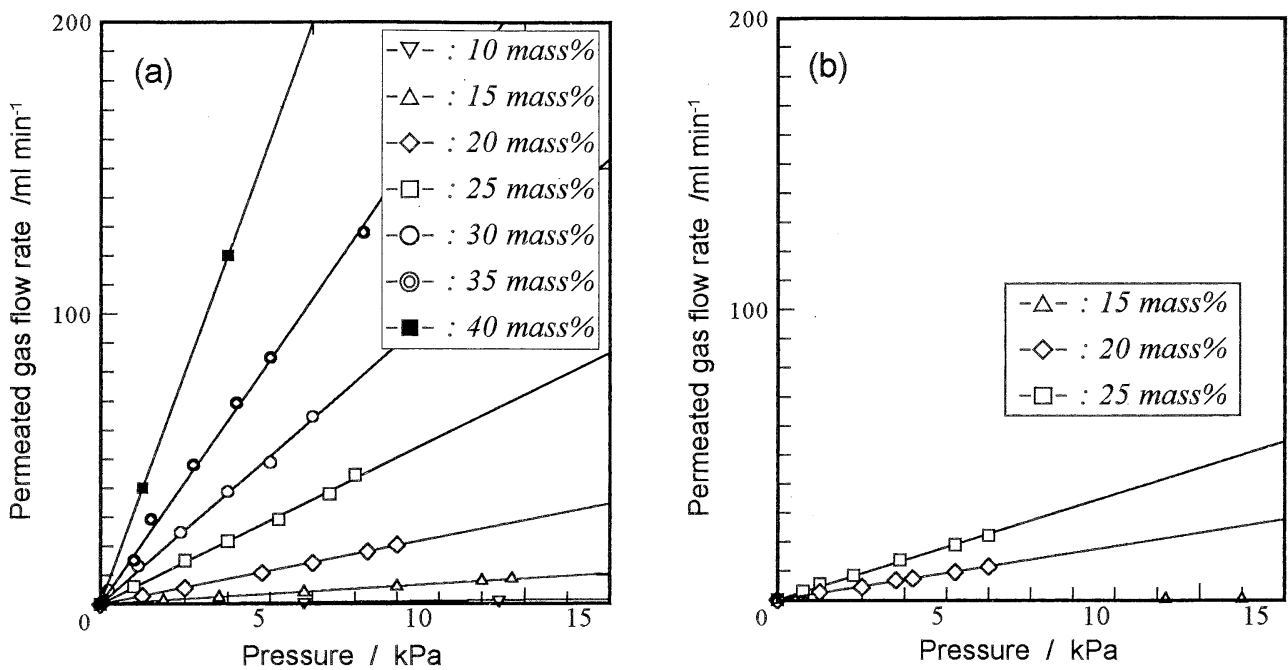

Fig. 6. Gas permeability of porous substrate at room temperature. Foaming agent: (a) wheat starch, (b) carbon black.

\section{2 ガス透過性に及ぼす発泡剤添加の影響}

図 6 (a)及び(b)に，発泡剤としてそれぞれ小麦デンプンと カーボンブラックを用いた場合の室温に扔けるガ入透過試験の 結果を示す。横軸には，大気圧を基準として導入した $\mathrm{N}_{2}$ ガス の圧力を, 縦軸には多孔質支持体を透過したガスの流量をプ ロットしてある. 導入ガスの圧力を大きくしていくと透過ガス 流量は直線的に増加していく様子が各グラフから確認できる。 更に，同じ発泡剤を用いた場合には，添加量の増加とともに透 過ガス流量が増加する傾向が認められる。 また，カーボンブ ラックを用いると焼結可能な発泡剤添加量範囲が狭く, 同じ添 加量で比較するととうもろこしデンプンよりもガス透過ガ入流 量は小さいことが分かる。

次に，グラフの傾きを“ガ久透過率” $\left(\mathrm{ml} \cdot \mathrm{min}^{-1} \cdot \mathrm{Pa}^{-1}\right)$ と 定義し，発泡剤の添加量に対するガス透過率を発泡剂別に比較 したものが図 7 である。この図から，ガス透過性の大小関係は

$$
\begin{aligned}
& \text { とうもろこしデンプン>小麦デンプン>ブドウ糖 } \\
& \text { ミカーボンブラック }
\end{aligned}
$$

であることが分かる。この結果は, 平均細孔径の大小関係とも

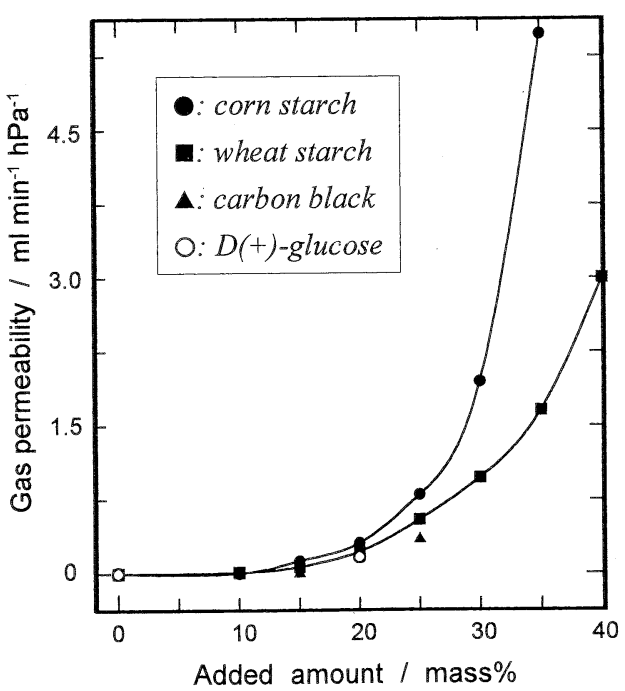

Fig. 7. Gas permeability plotted against the added amount of foaming agent.
よく対応しており，細孔サイズがガ入透過性の大きさを左右す る重要な因子となっていることを示唆している (表 1 参照). また，すべての曲線において発泡剤の添加量の増加に対して加 速的な増加を示す傾向が見られる。添加量が少いとき，細孔は 他の細孔パスと接合することなく，限られた通気経路を形成す る。その結果，ガスが拡散しにくい複雑なパスを形成し，しか も透過距離も長い。また，ガス透過に関与しないクローズドポ アの割合も多い。一方, 添加量が多くなると，透過ガ久の拡散 パスがより多岐にわたり，しかも細孔径が大きくなる。このよ うに，定性的ではあるが，発泡剂の添加量に対しガス透過性が 上述のように急激に増加することを細孔生成機構から説明する ことができる。

\section{3 多孔質支持体の評価}

混合導電体薄膜のスピンコーティングに適した多孔質支持体 を得るための条件を選択するために，作製した試料の評洒を 行った。図 8 に各種発泡剂を用いた場合のガス透過率と平均細 孔径との関係をなとてある。図中の数字は添加量（mass\%)

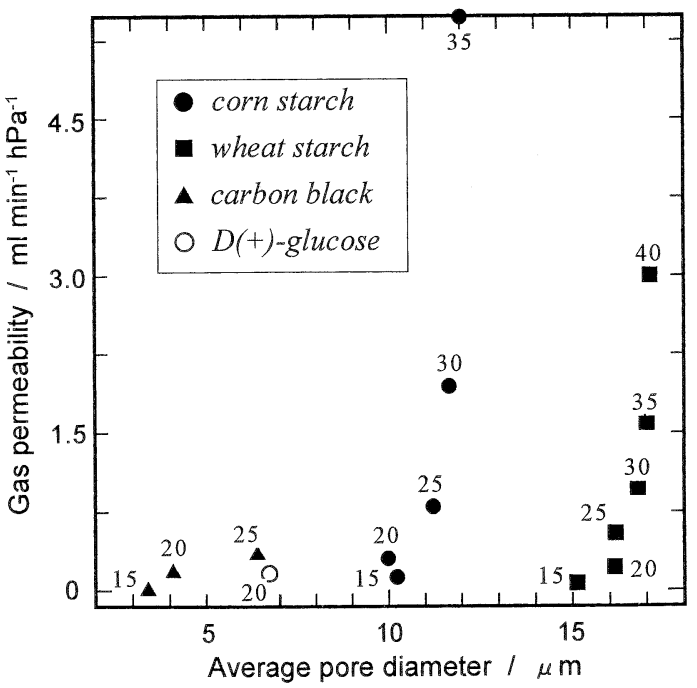

Fig. 8. Correlation between gas permeability and average pore diameter at various added amounts of the foaming agents. The number entered near the plot shows the added amount (mass\%) of foaming agent. 
の值を示す。この図から，必要なガ久透過率は発泡剤の種類及 び添加量（又は平均細孔径）により選択することができること が分かる，以上の結果から，本研究で目的とするようなガス透 過率が高く，かつ機械的強度に優れた混合尊電体薄膜用の多孔 質支持体の候補として，カーボンブラック 20 mass\%又は小麦 デンプン 40 mass\%を添加して得られた試料を選択し，実際に これらの支持体上に混合導電体 $\mathrm{Ca}(\mathrm{Ti}, \mathrm{Fe}) \mathrm{O}_{3}$ 薄膜のスピン コーティングを施し，その微構造を観察した。図 9 に，両者の 発泡剂を添加して得られた多孔質支持体に $\mathrm{Ca}(\mathrm{Ti}, \mathrm{Fe}) \mathrm{O}_{3}$ 薄膜 をスピンコーティングし6)，グリーン膜を $1235^{\circ} \mathrm{C}, 2 \mathrm{~h}$ 焼結する サイクルを 3 回繰り返して得られた試料の破断面の SEM 写真 を示す． 3 回の熱サイクル後に掞いても焼結膜のはく離はな く，多孔質支持体の表面に均一な緻密膜が被覆されている様子

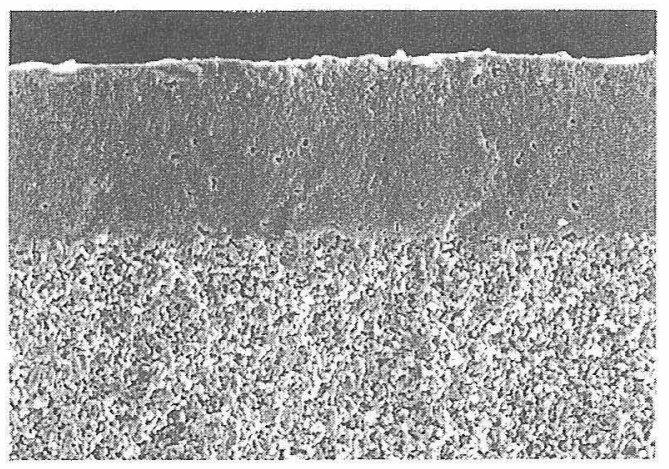

a

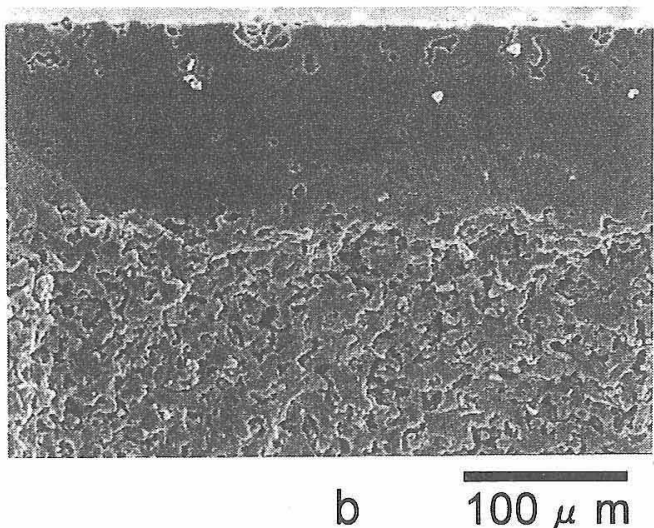

Fig. 9. SEM photographs of the cross sections of the porous substrates spin-coated with $\mathrm{Ca}(\mathrm{Ti}, \mathrm{Fe}) \mathrm{O}_{3}$ film. Foaming agent: (a) 20 mass \% carbon black, (b) 40 mass \% wheat starch. Spin-coating and sintering repetition number: 3 times.
が分かる、このことから，この試料の熱・機械的強度が良好で あることが明らかである，図 5 及び表 1 に示したように，発 泡剂添加量の増加とともに，多孔質体の気孔率が増加し，焼結 性と機械的強度が低下する傾向がある。したがって，機械的強 度の観点からは，カーボンブラック 20 mass\%添加の多孔質体 のほうが優れていると考えられる. しかし，両者の優劣につい ては，多孔質支持体上へのスピンコーティングによる混合導電 体の成膜性や膜一焼結体界面の微構造, 更に多孔質支持体と混 合尊電体薄膜からなる電気化学的デバイスに抢ける酸素の透過 性などの観点から総合的な比較評洒が必要であり，これは別の 報告とず る6)。

\section{4. 総 括}

酸素ガスの電気化学的抽出器に用いる混合導電体 $\mathrm{Ca}(\mathrm{Ti}$, $\mathrm{Fe}) \mathrm{O}_{3}$ 薄膜用の多孔質 $\mathrm{CaTiO}_{3}$ 支持体を暁成発泡法により作製 し，次のような最適調製条件を得た。

（1）発泡剂としてデンプン類を用いると，比較的大きな気 孔が生成し, 焼結可能な発泡剂添加量範国は広い。カーボンブ ラックやブドウ糖を用いた場合には，細孔径が小さく，燒結可 能な発泡剂添加量範囲は狭い。また，いずれの発泡剂でも，気 孔率は添加量とともに増加するが，その増加率は減少する。

（2）ガス透過率は，発泡剤の種類及び添加量に依存し，一 定の添加量では，とうもろこしデンプン>小麦デンプン>ブド ウ糖ミカーボンブラックの順に減少する。 また，同じ発泡剂を 用いた場合のガス透過率は添加量とともに加速度的に増大す る.

（3）カーボンブラック 20 mass\% \% 小麦デンプソ 40 mass\%を添加して作製した多孔筫焼結体は熱・機械的強度に 優れ，密着性のよい緻密な $\mathrm{Ca}(\mathrm{Ti}, \mathrm{Fe}) \mathrm{O}_{3}$ 膜のスピンコーティ ングのための支持体として適している。

\section{女献}

1）中 重治，早川 茂編，“電子材料セラミックス”, オーム社 (1986) pp. 15-29.

2) H. Iwahara, T. Esaka and T. Mangahara, J. Appl. Electrochem., 18, 173-77 (1988).

3) T. Esaka, T. Fujii, K. Suwa and H. Iwahara, Solid State Ionics, 40/41, 544-47 (1990)

4) 岩原弘育, 電気化学, 63, 707-11 (1995)

5) H. Itoh, I. Oikawa, H. Iwahara and M. Aizawa, J. Mater. Sci., 30, 2139-44 (1995).

6) H. Itoh, H. Asano, K. Fukuroi, M. Nagata and H. Iwahara, $J$. Am. Ceram. Soc. 80, 1359-65 (1997).

7）寺岡靖剛, 福田泰三, 三浦則雄, 山添 曻, セラミックス諭 文誌, 97, 467-72 (1989). 